PIOTR CHUDZIK ${ }^{1}$, GRZEGORZ LISOWSKI ${ }^{1}$

JERZY ZGRAJA ${ }^{2}$, LUKASZ KAZIMIERSKI ${ }^{1}$

${ }^{1}$ Politechnika Lódzka, Instytut Automatyki

${ }^{2}$ Politechnika Lódzka, Instytut Informatyki Stosowanej

\title{
UKŁADY POMIAROWE DO IDENTYFIKACJI OBCIĄŻENIA I WYZNACZANIA MOCY W GENERATORZE LLC DO NAGRZEWANIA INDUKCYJNEGO
}

$W$ artykule przedstawiono uktady pomiarowe zastosowane $w$ generatorze do nagrzewania indukcyjnego. Omówiono ich budowę oraz sposób dotączenia do systemu sterowania falownikiem napięcia. Przedstawiono również wymagania stawiane tym układom przez algorytmy wyznaczająe parametry obciażenia i moc wydzielana $w$ generatorze.

\section{WSTEP}

Generator LLC do nagrzewania indukcyjnego jest urządzeniem, w którym za pomocą sterowania falownikiem napięcia utrzymuje się we właściwym punkcie pracy układ o topologii LLC (układ trzeciego rzędu). Za powstawanie drgań, niezbędnych do wywołania efektów grzejnych we wzbudniku, odpowiadają: indukcyjność pomocnicza Ls, indukcyjność wzbudnika Lobc oraz pojemność kondensatora rezonansowego $\mathrm{Cr}$. Na działanie układu mają również wpływ indukcyjności połączeń poszczególnych części składowych generatora.

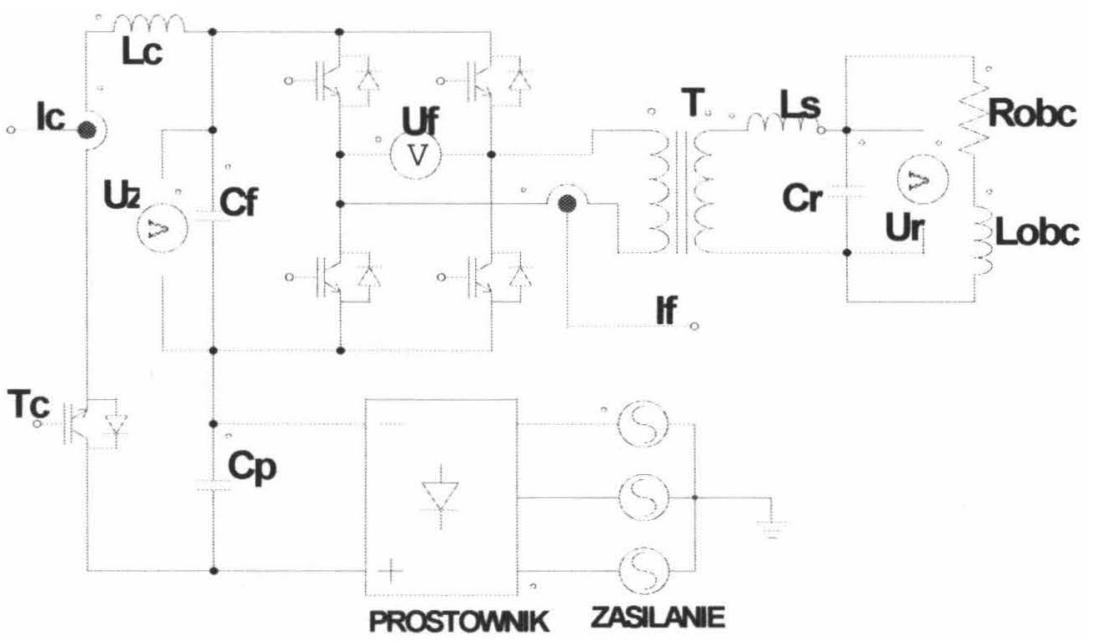

Rys. 1. Schemat połączeń części silnoprądowej jednego toru układu generatora o topologii LLC 
Na rysunku 1 umieszczono schemat ideowy obwodów silnoprądowych urządzenia. Ze względu na potrzebę zapewnienia elastyczności działania urządzenia przyjęto założenie, że układ można konfigurować poprzez odpowiednie dobieranie pojemności $\mathrm{C}_{\mathrm{r}}$, zmianę wartości dławika regulacyjnego $\mathrm{L}_{\mathrm{s}}$ oraz zmianę samego wzbudnika. Ponadto sam wzbudnik może zmieniać w bardzo szerokim zakresie swoje parametry w zależności od umieszczonego w nim wsadu, jego temperatury oraz amplitudy i częstotliwości wymuszanego prądu. Zapewnienie odpowiednich warunków pracy $\mathrm{w}$ obwodach generatora wiąże się z wymuszeniem w falowniku napięcia o określonej amplitudzie i częstotliwości. W przypadku tak złożonego dynamicznie układu, dodatkowo obarczonego silną zmiennością parametrów oraz często brakiem informacji o nagrzewanym obiekcie, nie jest możliwe osiągnięcie optymalnych warunków pracy bez przynajmniej zgrubnej znajomości wszystkich pojemności i indukcyjności biorących udział w procesie nagrzewania. Informacja o wartościach parametrów obwodu LLC jest potrzebna nie tylko do samego zainicjowania procesu, ma również bardzo duże znaczenie podczas całego czasu jego trwania ze względu na silną zmienność indukcyjności wzbudnika $\mathrm{z}$ umieszczonym w nim wsadem. $\mathrm{W}$ ramach projektu generatora podjęto próbę wyznaczania wybranych parametrów elementów obwodu na podstawie dostępnych pomiarowo wielkości napięć i prądów. Ze względu na wykorzystywanie w układzie częstotliwości sięgających setek kiloherców oraz występowanie zjawisk rezonansowych, związanych ze znacznymi mocami biernymi istnieje potrzeba bardzo dokładnego mierzenia dostępnych prądów i napięć, ze szczególnym uwzględnieniem wrażliwości układów wyliczających wielkości mierzone na błędy przesunięcia w fazie lub czasie.

\section{POMIARY PRĄDÓW I NAPIĘĆ W ELEMENTACH GENERATORA}

W generatorze przedstawionym na rys. 1 wielkościami mierzonymi w obwodach mocy są prąd wejściowy falownika $I_{c}$ oraz prąd wyjściowy falownika $I_{f}$. W przypadku prądu wejściowego (zasilania) falownika, który ma wolnozmienny charakter ze znaczącą składową stałą, użyto powszechnie stosowanych w przemyśle przetworników opierających swoje działanie na czujnikach Halla. Ten typ przetworników jest bardzo popularny, głównie dzięki łatwości stosowania, możliwości wykonywania pomiarów bez ingerencji w badany układ oraz zadowalającej dla większości układów przemysłowych dokładności. Niestety, w przypadku pomiarów prądów wyjściowych falownika czujniki te nie pozwalają osiągnąć zadowalającej dokładności. Prądy układów rezonansowych osiągają bowiem częstotliwości sięgające setek kiloherców. W tych warunkach pracy typowe przemysłowe czujniki wykazują znaczne błędy fazowe, które są niedopuszczalne, szczególnie ze względu na moce bierne, 
nieodłącznie związane $\mathrm{z}$ rezonansowym charakterem działania generatora. Dostępne na rynku laboratoryjne układy pomiarowe, które posiadają odpowiednie możliwości, są z kolei zbyt drogie dla zastosowań w urządzeniach przeznaczonych do produkcji seryjnej. W celu osiągnięcia wymaganych dokładności dla mierzonych w układzie prądów wyjściowych falownika zastosowano przekładnik prądowy, którego prąd uzwojenia wtórnego jest mierzony na boczniku przez układ wzmacniacza różnicowego (rys. 2). Takie rozwiązanie zapewnia eliminację bardzo kłopotliwej dla układów pomiarowych dużej szybkozmiennej składowej wspólnej, która pojawia się na skutek pojemnościowego sprzężenia wyjściowego przewodu falownika $\mathrm{z}$ przekładnikiem, wysokoczęstotliwościowych zakłóceń przewodu pomiarowego oraz wysokoczęstotliwościowego oddziaływania tranzystorów falownika na kartę sterująco-pomiarową. Jedynym ograniczeniem wynikającym ze stosowania przekładnika jest brak możliwości pomiaru składowej stałej. Tego typu ograniczenie nie jest jednak istotne w przypadku prądu wyjściowego falownika, ponieważ jako prąd uzwojenia pierwotnego transformatora $T, z$ założenia nie może on posiadać składowej stałej.

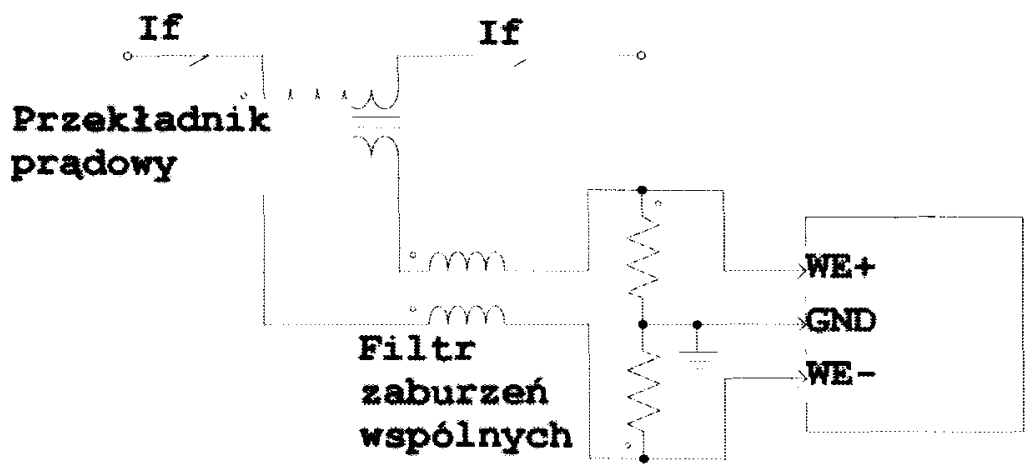

Rys. 2. Schemat układu pomiarowego prądów w generatorze

Podobnie jak w przypadku prądów, tam gdzie nie występują wysokie stromości narastania napięć, do ich pomiarów można stosować typowe, przemysłowe przetworniki wykorzystujące czujniki Halla. W generatorze tego typu czujniki zostały użyte do pomiarów napięć zasilania falownika $U_{z f}$. Najbardziej kłopotliwym do pomiaru sygnałem o charakterze napięciowym jest napięcie wyjściowe falownika, które jest $\mathrm{w}$ generatorze napięciem uzwojenia pierwotnego transformatora $\mathrm{T}$. W klasycznych układach falownikowych często zamiast pomiaru tej wielkości korzysta się z matematycznego wyznaczenia jej na podstawie znajomości stanu tranzystorów i napięcia obwodu pośredniczącego falownika $U_{z f}$ [1]. Takie rozwiązania są akceptowalne przy niewielkich częstotliwościach falowników, gdy czas martwy i czas trwania zboczy nie stanowi znacznej części całego okresu pracy falownika. W układach, w których udział czasu martwego jest znaczny, niezbędne jest korzystanie z szybkich 
pomiarów napięcia. W przypadku częstotliwości $80 \mathrm{kHz}$ okres wyjściowej fali napięciowej wynosi 12,5 us. Czas martwy na poziomie 1 us stanowi aż $8 \%$ okresu, co po przyjęciu dwóch przełączeń na okres powoduje, że napięcie rzeczywiste znacznie różni się od napięcia wynikającego ze współczynnika modulacji i silnie zależy od charakteru obciążenia [2]. Na rysunku 3 przedstawiono przebieg napięcia wyjściowego falownika $U_{f}$ na tle sygnału sterującego załączanego tranzystora. Na przebiegach widoczna jest różnica między chwilą wysterowania tranzystora a rzeczywistym jego przełączeniem, wynikająca $\mathrm{z}$ obecności czasu martwego, niezbędnego do zapewnienia bezpiecznego działania tranzystorów. Przełączenie przedstawione na przebiegu dotyczy obciążenia o charakterze indukcyjnym - zmiana napięcia wyjściowego następuje w chwili „twardego" wyłączenia pierwszej pary tranzystorów (po upływie 625 ns od zainicjowania wyłączania.

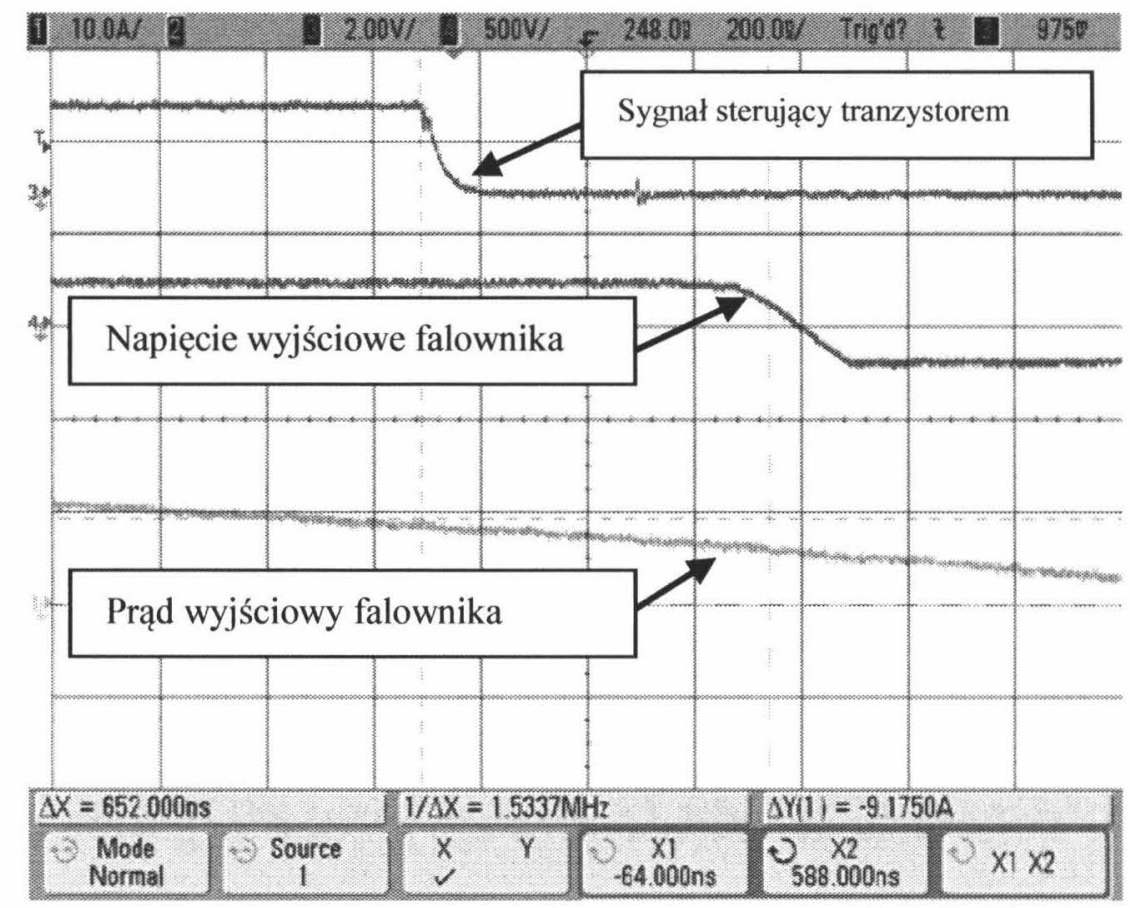

Rys. 3. Przebiegi napięcia wyjściowego falownika na tle sygnału sterującego jednego $\mathrm{z}$ tranzystorów falownika

Ze względu na bardzo duże znaczenie pomiaru rzeczywistych wartości napięcia wyjściowego falownika, w układzie został wykorzystany dzielnik rezystancyjny z pojemnościami kompensującymi (o konstrukcji typowej sondy napięciowej), którego napięcie wyjściowe jest mierzone wejściowym wzmacniaczem różnicowym karty pomiarowej (rys.4). Takie rozwiązanie pozwala na eliminację opóźnień pomiarowych. Jego wadą jest brak separacji galwanicznej między potencjałami obwodów strony pierwotnej generatora a układem pomiarowym. Z tego względu dobrano tak wartość dzielnika napięciowego i wzmocnienia wzmacniaczy, aby wartości maksymalnych potencjałów falownika nie wykraczały poza zakres napięciowy wzmacniaczy. 


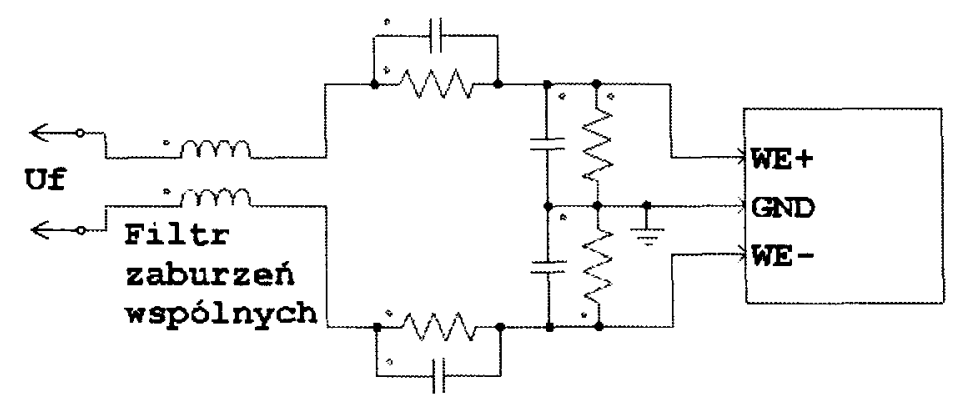

Rys. 4. Schemat układu pomiarowego napięć szybkozmiennych

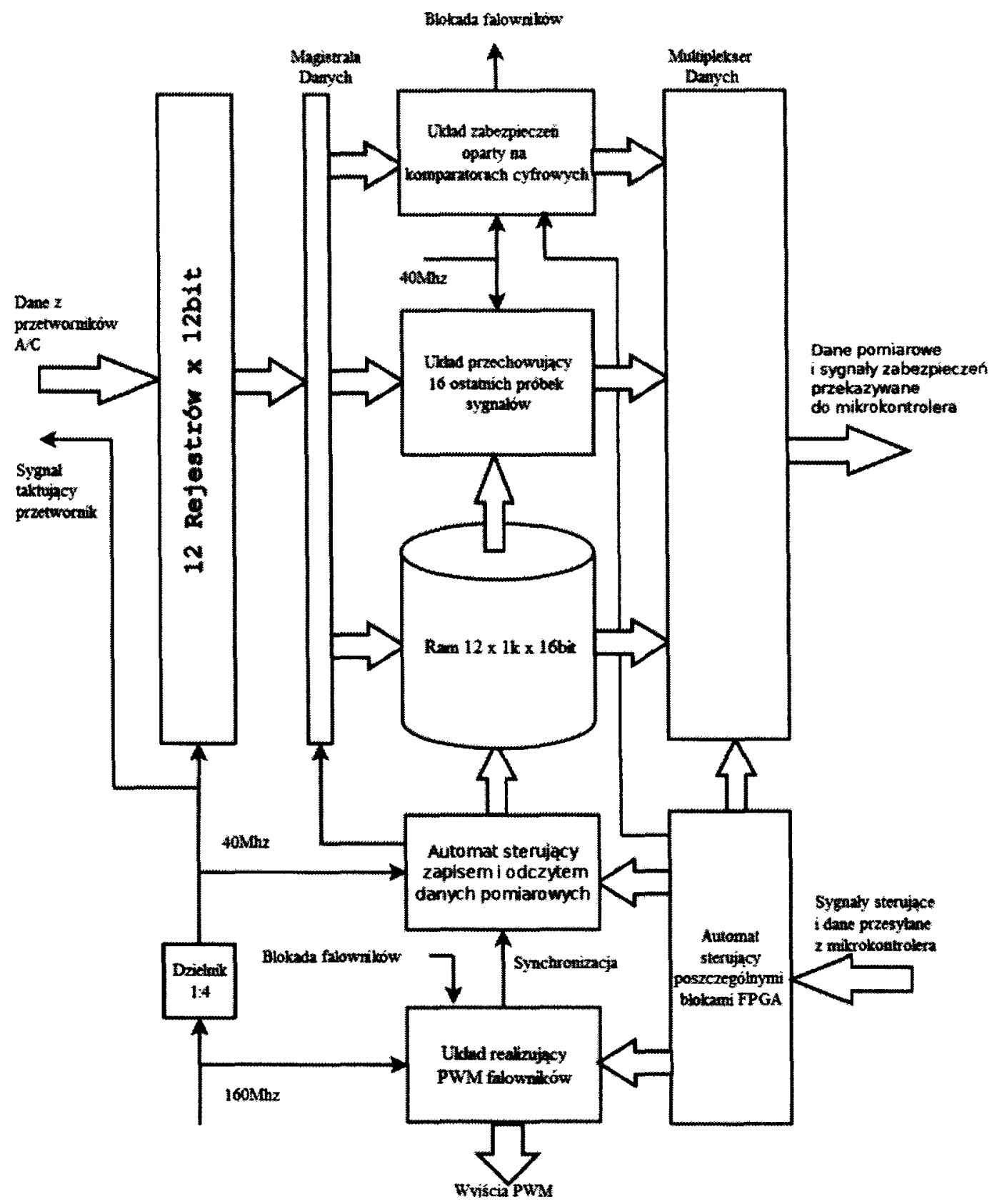

Rys. 5. Schemat struktury FPGA, odpowiedzialnej za realizację pomiarów analogowych i zabezpieczeń

Wszystkie wielkości mierzone $\mathrm{w}$ układzie generatora są dostarczane do jednakowych 12 wejść pomiarowych, z których każde ma strukturę 
wzmacniacza różnicowego. Pobrane sygnały podlegają obróbce w systemie sterowania, którego istotną część stanowi układ FPGA. Działanie układu polega na wykonaniu jednoczesnego pomiaru we wszystkich kanałach wejściowych. Po pobraniu danych system przechowuje po 16 ostatnich pomiarów dla każdego z kanałów. Zapamiętane wartości, poprzez multiplekser danych, mogą być przekazane w szybki sposób do mikrokontrolera. Struktura tego układu została zamieszczona na rysunku 5. System pomiarowy poza samą rejestracją wykonuje również zadania zabezpieczenia nadprądowego i nadnapięciowego.

\section{IDENTYFIKACJA OBCIĄŻENIA I WYZNACZANIE MOCY W GENERATORZE}

Bardzo duże wymagania w stosunku do jakości pomiaru napięć i prądów w systemie wynikają $\mathrm{z}$ potrzeby wykonania, w sposób automatyczny, identyfikacji obciążenia, które zostało umieszczone we wzbudniku generatora. Proces identyfikacji wiąże się $\mathrm{z}$ kontrolowanym załączeniem napięcia sterującego w taki sposób, aby wielkości pomiarowe osiągnęły poziom pozwalający na uzyskanie zamierzonej dokładności wyznaczanych na ich podstawie parametrów [3]. Charakterystyczną cechą układów wykorzystujących zjawisko rezonansu jest znaczny udział mocy biernej na tle całkowitej mocy przetwarzanej w urządzeniach. W tej sytuacji szczególnego znaczenia nabiera zgodność fazowa rzeczywistych wielkości mierzonych $\mathrm{z}$ ich reprezentacją w postaci zarejestrowanych wartości. Z punktu widzenia wrażliwości wyznaczanego parametru (rezystancja i indukcyjność wsadu) na jakość pomiaru, zgodność ta ma zasadnicze znaczenie szczególnie w sytuacji pomiarów wielkości przesuniętych $\mathrm{w}$ fazie o kąty bliskie 90 stopni. $\mathrm{Na}$ rysunku 6 zamieszczono przykładowe przebiegi mierzonych w systemie wartości napięcia falownika, prądu uzwojenia pierwotnego transformatora separującego oraz napięcia na kondensatorze rezonansowym. W czasie pracy systemu $\mathrm{w}$ przedstawionych na rysunku 6 przypadkach wyliczone zostały następujące wartości mocy:

Tabela 1

\begin{tabular}{|c|c|c|}
\hline Częstotliwość & $f=42400 \mathrm{~Hz}$ (rezonans) & $f=50000 \mathrm{~Hz}$ \\
\hline $\begin{array}{c}\text { Moc wejściowa } \\
\text { (mierzona na zasilaniu DC) }\end{array}$ & $7.863 \mathrm{~kW}$ & $0.528 \mathrm{~kW}$ \\
\hline Moc wyjściowa falownika & $7.705 \mathrm{~kW}$ & $0.332 \mathrm{~kW}$ \\
\hline
\end{tabular}

W ramach prowadzonych badań dokonano również obliczenia wartości mocy na podstawie pomiaru prądu $\mathrm{w}$ uzwojeniu pierwotnym transformatora i napięcia na kondensatorze rezonansowym. Dla stanu rezonansu otrzymano następujące wyniki: 
Moc wejściowa (obliczana na obwodzie zasilania falownika) $P_{D C}=7.863 \mathrm{~kW}$, Moc wyjściowa(obliczana z napięcia wyjściowego falownika) $P_{W Y}=7.705 \mathrm{~kW}$, Moc wyjściowa (obliczana na obwodzie rezonansowym) $P_{W Y}=8.847 \mathrm{~kW}$.
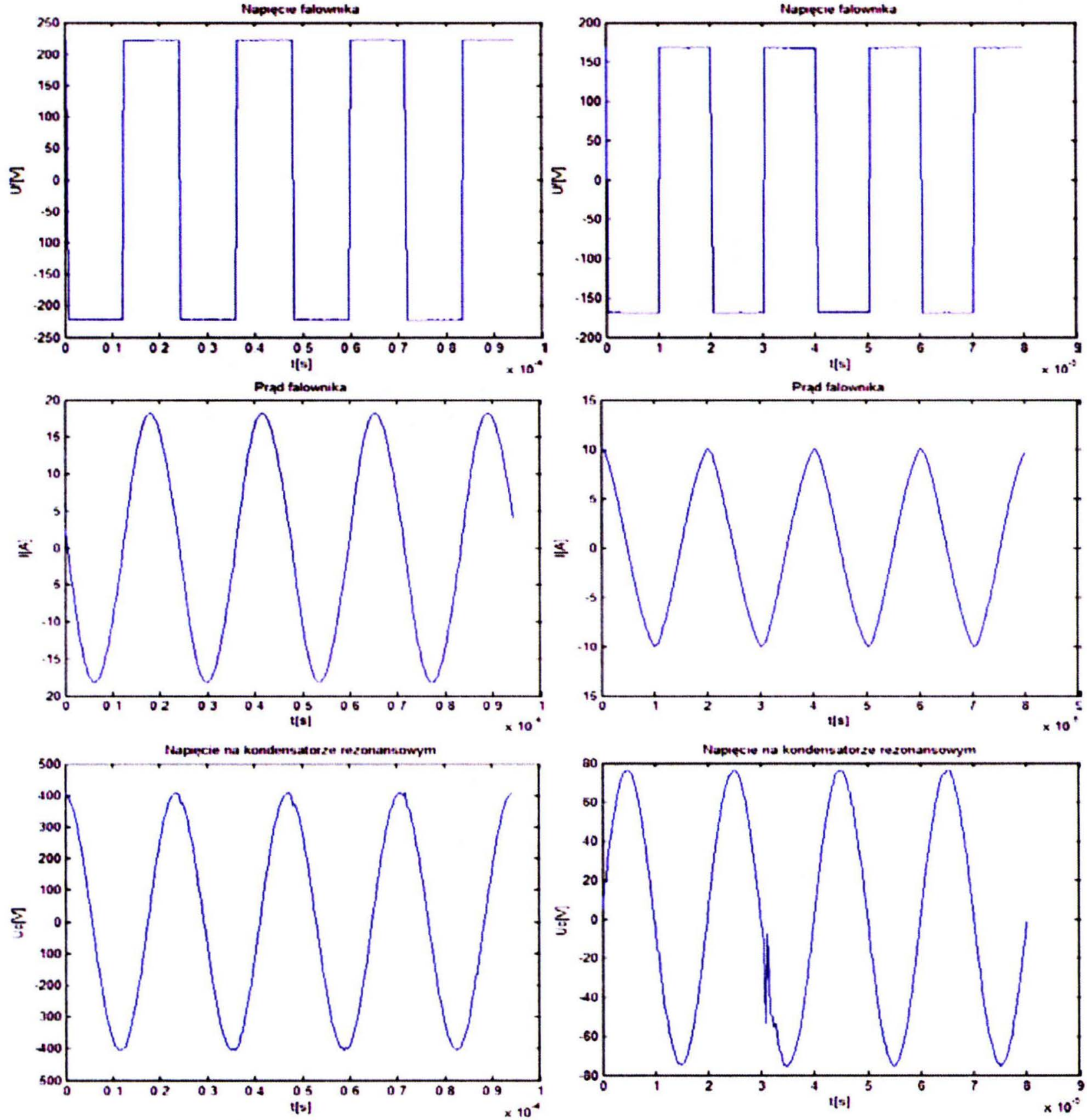

Rys. 6. Przykładowe przebiegi napięć i prądów w generatorze przy pracy w rezonansie $f=42400 \mathrm{~Hz}$ (kolumna lewa) oraz przy pracy z wyższą częstotliwością $-f=50000 \mathrm{~Hz}$ (kolumna prawa)

Otrzymane wartości świadczą o znacznym błędzie w pomiarze wartości mocy popełnianym podczas jej obliczania na podstawie wartości napięcia na kondensatorze rezonansowym (rys. 7). Analiza wrażliwości wpływu dokładności pomiarów na oszacowanie mocy wyjściowej pokazała, że dla rozważanego 
przypadku błąd fazowy o wartości 1 stopnia kątowego, popełniany w pomiarze napięcia na kondensatorze rezonansowym, jest przyczyną aż $20 \%$ błędu w wyznaczaniu wartości mocy wyjściowej, co praktycznie eliminuje ten sposób pomiaru.

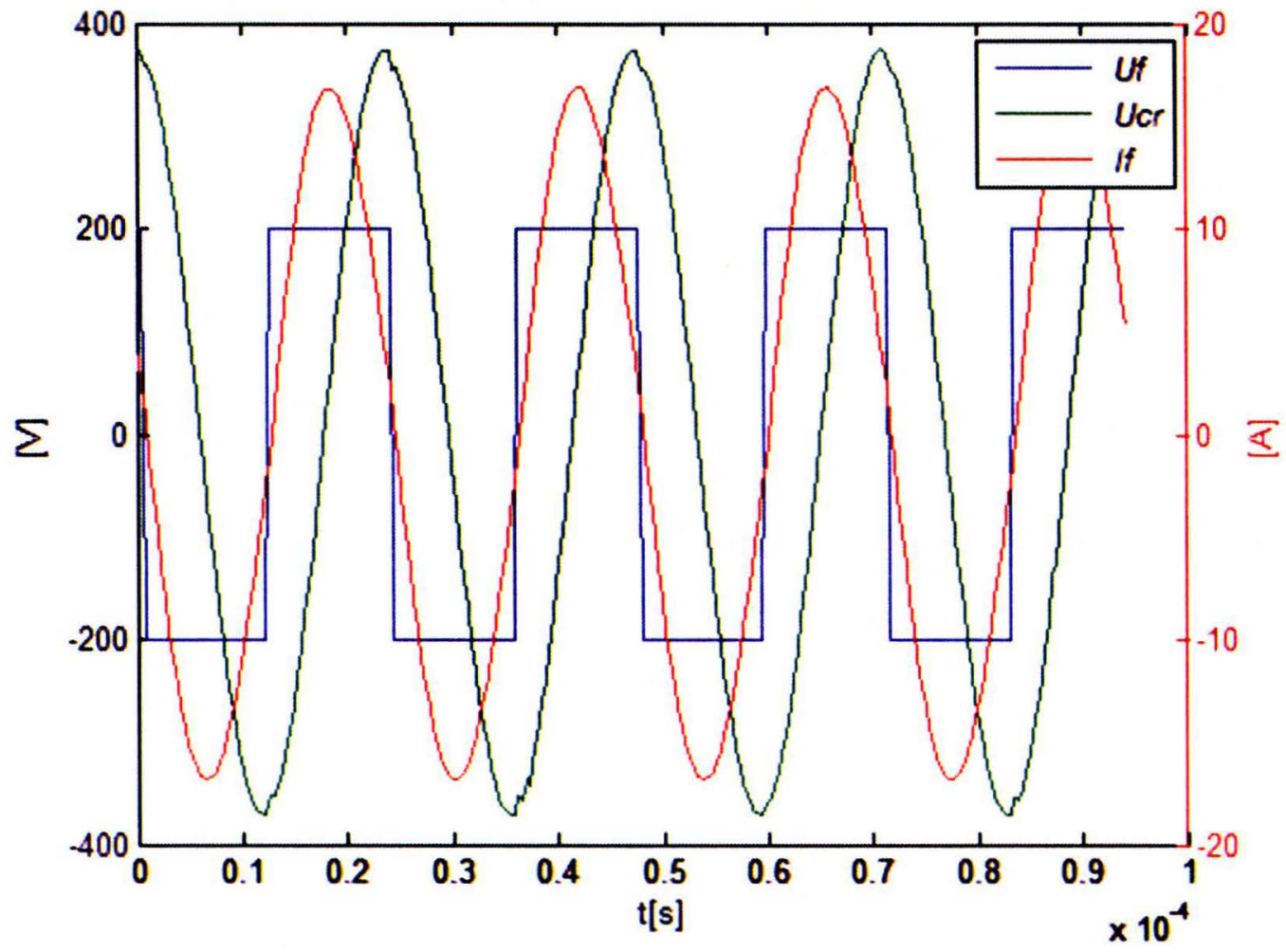

Rys. 7. Przykładowe przebiegi napięć i prądów w generatorze przy pracy w rezonansie $-f=42400 \mathrm{~Hz}$, pokazujące znaczne przesunięcie fazowe między napięciem na kondensatorze rezonansowym i prądem wzbudnika

Podczas przeprowadzania identyfikacji za pomocą załączania napięcia do wzbudnika ze wsadem o nieznanych parametrach, bardzo ważne jest zabezpieczenie nagrzewanego detalu przed zniszczeniem. Ze względu na bardzo krótkie czasy nagrzewania elementów i opóźnienia pomiarowe wnoszone przez urządzenia mierzące temperaturę, nie ma możliwości zabezpieczenia wsadu na podstawie samych pomiarów temperatury (które to pomiary nie zawsze są $\mathrm{w}$ praktyce realizowane). $\mathrm{W}$ omawianym generatorze zastosowano, działający w czasie rzeczywistym, algorytm ograniczania dostarczanej do wsadu energii, który wyznacza tę energię $\mathrm{z}$ mierzonych wartości napięć i prądów. Gdy wyliczona przez układ pomiarowy energia przekracza założoną wartość maksymalną, generator zostaje wyłączony.

Poza samym procesem identyfikacji układy pomiarowe i algorytmy wyznaczające parametry układu pełnią kluczową rolę w wyznaczaniu wielkości sterujących generatorem $\mathrm{w}$ trakcie normalnej pracy. Układy do nagrzewania indukcyjnego, w przeciwieństwie do typowych rezonansowych przetwornic DC/DC, charakteryzują się dużą zmiennością częstotliwości rezonansowej 
w trakcie trwania procesu na skutek zmiany amplitudy prądu i temperatury wsadu. Aby w takich warunkach możliwa była pełna kontrola procesu nagrzewania, niezbędna jest cięgła analiza sygnałów, prowadzona $w$ czasie rzeczywistym i uwzględnianie wyników pomiarów w algorytmie sterowania [4]. Jednym $\mathrm{z}$ ważniejszych warunków właściwego działania tego typu algorytmów jest jakość mierzonych sygnałów. Szczególnie istotne jest zapewnienie zgodności fazowej pomiaru $\mathrm{z}$ przebiegiem rzeczywistym oraz eliminacja zaburzeń typowych dla układów $\mathrm{z}$ falownikami tranzystorowymi.

\section{PODSUMOWANIE}

Przeprowadzone badania układów pomiarowych laboratoryjnego generatora do nagrzewania indukcyjnego pokazały bardzo dużą rolę, jaką pełni w procesie identyfikacji, zabezpieczaniu i normalnej pracy możliwość obliczania w czasie rzeczywistym wartości wybranych parametrów układu na podstawie szybkich pomiarów napięć i prądów.

\section{LITERATURA}

[1] Jong Woo Choi, Sung Il Yong, Seung Ki Sul: Inverter Output Voltage Synthesis Using Novel Dead Time Compensation. IEEE 0-7803-1456-5/94, 1994, ss. 100-106.

[2] Nowak R., Chudzik P. Sobieraj T.: Wektorowy falownik napięciowy z pomiarem rzeczywistego napięcia wyjściowego. Napędy i Sterowanie, $\mathrm{Nr}$ 4/2014, ss. 70-73.

[3] Kucharski J., Frączyk A., Urbanek P., Jaworski T.: Projekt inteligentnego generatora w.cz. do indukcyjnego nagrzewania wsadów, Przegląd Elektrotechniczny, R. 90, Nr 2, 2014, ss. 20-23.

[4] Kobos W., Zgraja J., Chudzik P.: Analysis of dual-frequency generators structures for induction heating, Materiały konferencji:HES-13. International Conference on Heating by Electromagnetic Sources. Induction, Dielectric and Microwaves, Conduction and Electromagnetic Processing. Padwa, 2013, ss. 261-268.

Praca finansowana ze środków NCBiR w ramach projektu Badań Stosowanych nr umowy PBS1/A4/2/2012. 
MEASUREMENT SYSTEMS

FOR LOAD IDENTIFICATION AND POWER CALCULATION IN LLC INDUCTION HEATING GENERATOR

\section{Summary}

The paper describes measurement systems used in induction heating generator. Their build and connecting to the control system of voltage converter had been presented. The requirements resulting from algorithms which calculate load parameters and power absorbed by the load had been shown.

Keywords: induction heating generator, resonance converter, power measurement. 